\title{
Factors Determining Drug Uptake During Mass Drug Administration in Banyuasin District, South Sumatera, Indonesia
}

\author{
Indri Wulandari Putri, Rini Mutahar, Rico Januar Sitorus, Novrikasari, Amrina Rosyada, Desheila \\ Andarini
}

\begin{abstract}
The community participation in taking drugs to prevent filariasis can reduce the risk of contracting filariasis, especially those who live in filariasis-endemic areas. People who do not take filariasis medication at the time of filariasis through mass drug administration (MDA) will be more at risk for contracting filariasis. WHO filariasis program target on 2000 stated that the minimum MDA coverage that must be achieved to break the chain of transmission is $85 \%$, while the Banyuasin district has not reached the set target. This study aims to identify the factors determining drug uptake during Mass Drug Administration in Banyuasin District 2018. This study used a cross-sectional study design, the sample of this study was 200 samples of heads of families selected in a cluster random sampling. The analysis method of this study uses univariate, bivariate using the chi-square test and multivariate using multiple logistic regression tests. The results of this study found that the proportion of respondents taking filariasis drug was 75.5\%. The variables that significantly correlated with taking filariasis drug were attitudes (PR 1,89; 95\% CI 1.08-3.18) and support from Elimination Executing Staff (PR 2,06; 95\% CI 1,24-3,44). The behavior of taking medicine in the MDA FIlariasis activities in Banyuasin District was not good. Hence, health workers are expected to be more active in conducting counseling to improve community participation in the Filariasis MDA activities.
\end{abstract}

Keywords: Behavior; Filariasis; Mass Drug Administration (MDA).

\section{INTRODUCTION}

Filariasis (elephantiasis disease) is a chronic disease caused by filarial worms and is transmitted from various types of mosquitoes. It is estimated that $1 / 5$ of the world's population or 1.1 billion people in 83 countries are at risk of being infected with filariasis. In order to eradicate filariasis.

Revised Manuscript Received on September 22, 2019.

Indri Wulandari Putri, Faculty of Public Health Universitas Sriwijaya, Jln. Raya Palembang-Prabumulih KM.32 Indralaya, Ogan Ilir, 30862

Rini Mutahar, Faculty of Public Health Universitas Sriwijaya, Jln. Raya Palembang-Prabumulih KM.32 Indralaya, Ogan Ilir, 30862. rini_mutahar@fkm.unsri.ac.id

Januar Sitorus, Faculty of Public Health Universitas Sriwijaya, Jln. Raya Palembang-Prabumulih KM.32 Indralaya, Ogan Ilir, 30862

Novrikasari, Faculty of Public Health Universitas Sriwijaya, Jln. Raya Palembang-Prabumulih KM.32 Indralaya, Ogan Ilir, 30862

Amrina Rosyada, Faculty of Public Health Universitas Sriwijaya, Jln. Raya Palembang-Prabumulih KM.32 Indralaya, Ogan Ilir, 30862

Desheila Andarini, Faculty of Public Health Universitas Sriwijaya, Jln. Raya Palembang-Prabumulih KM.32 Indralaya, Ogan Ilir, 30862
WHO has declared the Global Program to Eliminate Lymphatic Filariasis (GPELF) as a Public Health Problem by the Year 2020 with two main strategies, namely termination of transmission by conducting mass treatment in endemic areas, preventing and limiting disability through the management of clinical cases of filariasis. ${ }^{21}$

Indonesia has been implementing a filariasis elimination program since 2002. Its mass treatment implementing unit is Regency/ City. Mass treatment aims to tackle down all the microfilariae that are in the blood of each resident at the same time so that they break the chain of transmission. Filariasis mass treatment uses a combination of Diethycarbamazine Citrate (DEC) drug $6 \mathrm{mg} / \mathrm{kg}$ body weight, Albendazole $400 \mathrm{mg}$ and Paracetamol $500 \mathrm{mg}$ given once a year for a minimum of 5 consecutive years. ${ }^{5}$

South Sumatra Province is one of the filariasis endemic areas. It is recorded that almost all districts in this province have chronic filariasis cases. Until 2014 there were 226 cases of chronic filariasis cases. Banyuasin Regency is the district with the highest filariasis cases compared to other districts/ cities, which are 142 cases with microfilaria (mf) rate which is $1.5 \% .{ }^{8}$ In 2017 it was noted that Banyuasin still ranks highest in filariasis cases in South Sumatra, which is a total of 89 cases spread across 18 sub-districts. ${ }^{7}$

Filariasis elimination program in Banyuasin Regency itself has been carried out in stages in all sub-districts since 2002. Although the provision during Mass Drug Administration (MDA) for filariasis prevention has been carried out for 5 consecutive years, through the evaluation results, Banyuasin District is still in the category of filariasis endemics. Based on data from 2008-2011 there were 142 chronic filariasis cases spread across 20 puskesmas areas with a $1.5 \% \mathrm{mf}$ rate. ${ }^{6}$

The involvement of residents in taking drugs to prevent filariasis can reduce the risk of contracting filariasis, especially those who live in filariasis endemic areas. Residents who do not take filariasis medication at the time of filariasis MDA activities will be more at risk for contracting filariasis, even though the population is taking drugs $>65 \%$. The results of the research conducted by Santoso showed that the proportion of the population with filariasis sufferings was found to be higher in the population who had never taken medication $(3.1 \%)$ compared to the population who took medicine $(0.6 \%)$. 
The results of the bivariate analysis showed a significant relationship between drug behavior and the risk of contracting filariasis $(\mathrm{p}=0.16){ }^{17}$

The target of the WHO filariasis program on 2000 stated that the minimum MDA coverage that must be achieved to break the chain of transmission is $85 \% .{ }^{20}$ On 2017, the coverage of taking filariasis medicine in Banyuasin District had increased by $82 \% .{ }^{7}$ Even though the coverage of the Phylary POMP in Banyuasin District has reached $80 \%$ or almost reached the target, this is only the data distribution of drug distribution at the Puskesmas. Has the drug given been actually taken by the community not yet carried out a survey. From the results of interviews during the initial survey with village cadres, there were still some people who did not ingest the filariasis prevention drugs.

The low coverage of filariasis elimination is caused by several factors including individual factors (age, sex, occupation, knowledge, education), community behavior (attitudes and knowledge) and environmental conditions. ${ }^{4}$

The research conducted by Nurlaila in Pekalongan City reported that most respondents who were obedient in taking medication were respondents who did not complete elementary school (92.3\%). ${ }^{14}$ Research conducted by Alamsyah said that respondents who worked 6 times more at risk of not taking filariasis prevention drugs than respondents who did not work. ${ }^{2}$

Research conducted in Berancah Village City said that compliance with filariasis mass treatment was more common in respondents who had good knowledge about filariasis $(67 \%)$ compared to respondents who had poor knowledge (17.5\%), the proportion of respondents who were positive about consuming filariasis drugs as much as $71.2 \%$.

The study by Ambarita reported that $76 \%$ of the 279 respondents who received the drug did not drink it. The reason for the respondents who were given the drug but did not drink it was fear of the side effects of the drug. ${ }^{3}$ Research conducted by Agus reported that respondents who had never received socialization from officers had a 7 times greater risk of not taking filariasis prevention drugs compared to respondents who received socialization by officers. ${ }^{10}$

Research conducted in Nepal said that there was a relationship between support by health cadres on compliance with taking filariasis medication. TPE support (Elimination Executing Staff) is a reinforcing factor of behavior. Motivation from the executors of filariasis or cadre elimination can be related to the scope of filariasis mass treatment and filariasis drug drinking behavior. ${ }^{13}$

Drug distribution is also one of the factors that influence the behavior of taking filariasis medicine. Dhading, Kapilvastu and Kailali (Nepal) used a house-to-house approach to distribute filariasis drugs to the community at home $(75.9 \%)$ when the filariasis mass treatment program was conducted. ${ }^{1}$

\section{METHODOLOGY}

This study is a quantitative analytical study with a cross-sectional study design. The sample in this study was the head of the family who were the target of the MDA as many as 200 respondents. Data analysis in this study was conducted in univariate, bivariate using chi-square test and multivariate using multiple logistic regression tests. The dependent variable of this study is the behavior of filariasis prevention drugs (medication) with independent variables are education, job status, knowledge of filariasis, attitudes towards filariasis, socialization from health workers, TPE support and drug distribution.

\section{RESULT AND FINDINGS}

The frequency distribution of the factors related to drinking behavior for preventive filariasis drugs in Banyuasin Regency can be seen in this table:

Table 1: Univariate Analysis of Factors Associated with Medication Behaviour for Filariasis Prevention in Banyuasin District

\begin{tabular}{|c|c|c|c|}
\hline Variables & Categories & $\mathbf{N}$ & Percentage \\
\hline \multirow[t]{2}{*}{$\begin{array}{l}\text { Medication } \\
\text { Behavior }\end{array}$} & $\begin{array}{c}\text { Taking } \\
\text { Medication }\end{array}$ & 151 & $75,5 \%$ \\
\hline & $\begin{array}{l}\text { Not Taking } \\
\text { Medication }\end{array}$ & 49 & $24,5 \%$ \\
\hline \multirow[t]{2}{*}{ Education } & Low & 144 & $72 \%$ \\
\hline & High & 56 & $28 \%$ \\
\hline \multirow[t]{2}{*}{ Job Status } & Work & 198 & $97 \%$ \\
\hline & Not Work & 6 & $3 \%$ \\
\hline \multirow{2}{*}{$\begin{array}{l}\text { Knowledge of } \\
\text { Filariasis }\end{array}$} & Poor & 87 & $43,5 \%$ \\
\hline & Good & 113 & $56,5 \%$ \\
\hline \multirow{2}{*}{$\begin{array}{c}\text { Attitude towards } \\
\text { Filariasis }\end{array}$} & Poor & 110 & $55 \%$ \\
\hline & Good & 90 & $45 \%$ \\
\hline \multirow[t]{2}{*}{$\begin{array}{l}\text { Socializations } \\
\text { from Health } \\
\text { Workers }\end{array}$} & There is no & 135 & $67,5 \%$ \\
\hline & There is & 65 & $32,5 \%$ \\
\hline \multirow[t]{2}{*}{ TPE Support } & Poor & 91 & $45,5 \%$ \\
\hline & Good & 109 & $54,5 \%$ \\
\hline \multirow[t]{2}{*}{ Drug Distribution } & Door-to-door & 180 & $90 \%$ \\
\hline & $\begin{array}{l}\text { Other than } \\
\text { door-to-door }\end{array}$ & 20 & $10 \%$ \\
\hline
\end{tabular}

Based on Table 1 above, from 200 respondents it can be seen that the majority of respondents who took filariasis prevention drugs were $75.5 \%$, with low education $72 \%$, the majority of working heads were $97 \%$, good filariasis knowledge was $56.5 \%$, attitudes towards filariasis were less than $55 \%$, family heads who did not receive socialization from health workers were $67.5 \%$, good TPE support was $54.5 \%$, and drug distribution by door-to-door approach was $90 \%$. 
Table 2: Bivariate Analysis of Factors Associated with Medication Behaviour for Filariasis Prevention in Banyuasin District

\begin{tabular}{cc}
\hline \multicolumn{3}{c}{ Medication } \\
Behavior \\
Not Taking \\
Variables \\
Taking \\
Medic Medicat \\
ation ion \\
\\
$\mathrm{n} \% \mathrm{~N} \%$ \\
\hline
\end{tabular}

Education

$\begin{array}{cccccccc}\text { Low } & 36 & 35, & 108 & 75 & 144 & 0,93 & 1,077 \\ & & 3 & & & & 6 & (0,619-1,874 \\ \text { High } & 13 & 23, & 43 & 76, & 56 & & \\ & 2 & & 8 & & & \end{array}$

Job Status

$\begin{array}{cccccccc} & & 23, & & 76, & & 0,32 & 0,474 \\ & 46 & 748 & 3 & 194 & 1 & (0,205-1,097\end{array}$

$\begin{array}{llllll}\text { Not Work } & 3 & 50 & 3 & 50 & 6\end{array}$

Knowledge of

Filariasis

\begin{tabular}{|c|c|c|c|c|c|c|c|}
\hline Poor & 22 & $\begin{array}{c}25 \\
3\end{array}$ & 65 & $\begin{array}{c}74 \\
7\end{array}$ & 87 & $\begin{array}{c}0,95 \\
1\end{array}$ & $\begin{array}{c}1,058 \\
(0,649-1,152\end{array}$ \\
\hline Good & 27 & $\begin{array}{c}23 \\
9\end{array}$ & 86 & $\begin{array}{c}76 \\
1\end{array}$ & 113 & & \\
\hline $\begin{array}{c}\text { Attitude } \\
\text { towards } \\
\text { Filariasis }\end{array}$ & & & & & & & \\
\hline Poor & 34 & $\begin{array}{c}30 \\
9\end{array}$ & 76 & $\begin{array}{c}69 \\
1\end{array}$ & 110 & $\begin{array}{c}0,03 \\
0\end{array}$ & $\begin{array}{c}1,855(1,081- \\
3,182)\end{array}$ \\
\hline Good & 15 & $\begin{array}{c}16 \\
7\end{array}$ & 75 & $\begin{array}{c}83 . \\
3\end{array}$ & 90 & & \\
\hline
\end{tabular}

Socializations

from Health

Workers

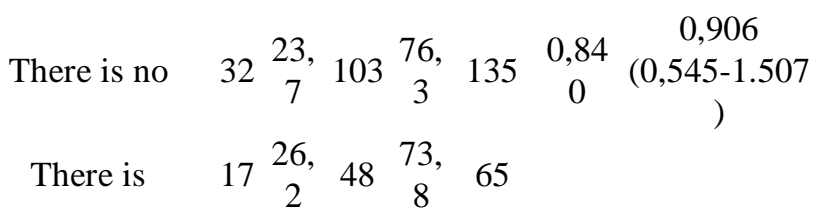

TPE Support

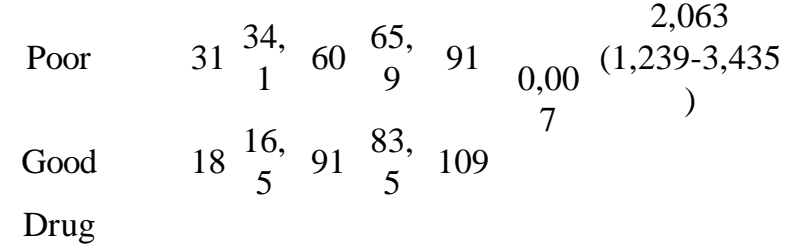

Distribution

$\begin{array}{lccccccc}\text { Door-to-door } & 41 & 22, & 77, & & 0,15 & 1,756 \\ 8 & 139 & 2 & 180 & 4 & (0,963-3,201 \\ & & & & & & \end{array}$

Other than

door-to-door

$\begin{array}{lllll}8 & 40 & 12 & 60 & 20\end{array}$

Based on Table 2 above, the results of statistical analysis using the Chi-square test indicate that there is a relationship between attitude variables towards filariasis ( $\mathrm{p}$-value = 0.030 ) and TPE support ( $\mathrm{p}$-value $=0.007$ ).
Table 3: Multivariate Analysis of Factors Associated with Medication Behaviour for Filariasis Prevention in Banyuasin District

\begin{tabular}{cccc}
\hline Variables & P-Value & PR $_{\text {adjusted }}$ & 95\% CI \\
\hline $\begin{array}{c}\text { Attitude towards } \\
\text { Filariasis }\end{array}$ & 0,061 & 1,956 & $0,969-3,948$ \\
TPE Support & 0,013 & 2,361 & $1,199-4,648$ \\
\hline
\end{tabular}

Based on Table 3 above, the results of multivariate analysis showed that the TPE support variable is the most influential factor on the medication behaviour of taking filariasis prevention drugs seen from significant variables and the highest PR adjusted value is 2.361 (95\% CI = 1.199-4.688). It can be interpreted that the head of the family who did not receive TPE support had a 2.361 times greater chance of not taking filariasis prevention drugs than the head of the family who received good TPE support after being controlled by attitude variables towards filariasis.

The results of this study indicate that as many as $24.5 \%$ of respondents did not take filariasis prevention drugs during mass treatment. Since some people are not aware of the existence of mass treatment so that the respondent did not receive medicine $(40.8 \%)$ and the public opinion that if they do not suffer from elephantiasis then no need to take elephantiasis prevention drug (44.9\%). Although a little but this can affect the success of the mass treatment being carried out as the head of the family has a strong influence in motivating his family members to participate in regular foot disease eradication programs in his area. ${ }^{16}$

In the health sector, a person's level of education plays a role in the ease of receiving information. Someone who has a high education is expected to receive information or messages of health better than someone with a low education. High and low levels of education affect the attitudes and behavior. The higher the level of one's education, the better the behavior. ${ }^{18}$ The results of this study state that there is no relationship between education and medication behavior. In the field of health, education is indeed influential in receiving health messages/ information, the level of education is less influential in a person's decision if the health information is not delivered equally to the community. ${ }^{10}$

The results of the statistical test of this study indicate that there is no relationship between work and behavior of taking filariasis prevention drugs. Respondents who work tend to be more obedient in filariasis mass treatment than those who do not work. Respondents who work more often get information so that knowledge related to filariasis mass treatment is also good. ${ }^{14}$

Knowledge is the result of knowing, after people have sensed a particular object. Knowledge is a domain that is very important for the formation of one's actions (over behavior). Someone who is well aware of health problems such as filarial prevention programs will be more amenable to ingesting filarial drugs, because he knows the benefits and uses of these drugs compared to people with low knowledge. 12 The results of this study

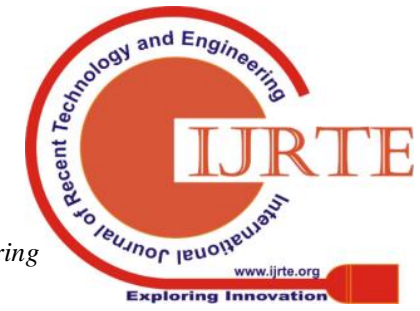


indicate that there is no relationship between knowledge and drug behavior. Even though theoretically, the increase in knowledge is in line with the increasing awareness in supporting the filariasis elimination program through POMP filariasis activities. ${ }^{11}$ This is caused by people who are very obedient to cadres/ TPE who instruct people to take filariasis prevention drugs even though the knowledge they get from TPE is very minimal.

The results of the analysis of this study found that there is a relationship between attitudes toward filariasis and medication behavior. The good attitude of the head of the family towards filariasis encourages respondents to take filariasis prevention drugs. ${ }^{5}$ In this study, there were still family heads with a positive attitude who did not consume filariasis prevention drugs as many as 15 respondents $(16.7 \%)$. This is due to a lack of experience of the head of the family to see the incidence of filariasis, so that there are heads of families who consider filariasis a harmless disease and the opinion of the head of the family on filariasis mass treatment aimed only at people with filariasis, so they assume that if they do not have the disease then it is not required to take the drug.

Socialization is very important to do before the granting of filariasis MDA to all levels of society in the regions that will receive mass treatment, the community must understand the causes and consequences of post-treatment follow-up events. ${ }^{15}$ The results of the statistical test of this study indicate that there is no significant relationship between the socialization of health workers and the behavior of taking filariasis prevention drugs. This is because in the research location, the socialization about filariasis is rarely done. Based on the results of the interviews, cadres at the research site said that the community was difficult to gathered. So that on the implementation of mass treatment, sometimes the cadres immediately deliver home remedies without any prior socialization regarding filariasis.

The results of statistical tests in this study indicate that there is a significant relationship between TPE support and mass drug behaviors to prevent filariasis. Motivation from Implementing Staff Elimination of filariasis or cadres can be related to the scope of filariasis mass treatment and filariasis drug drinking behavior. TPE informs people directly about the importance of taking filariasis medicine. They also will answer the questions of people around filariasis and make sure people take the medicine directly. ${ }^{4}$ In this study it was found that the TPE support provided still lacked, among others, TPE did not witness the possibility of side effects of anti-filariasis drugs (97\%), TPE did not inform the possibility of drug side effects (59\%), TPE did not inform that mass treatment would be carried out elephantiasis $(56.5 \%)$.

Based on multivariate analysis, it was found that there is a significant relationship between TPE support and preventive filariasis medication behavior $(\mathrm{p}$ value $=0.013)$ with $\mathrm{PR}=$ 2.361 which means that poor TPE support risked 2.3 times not to take filariasis prevention drugs compared to good TPE support.

The results of this study indicate that there is no

relationship between the distribution of drugs and medication behavior. Even though theoretically the efficiency of the filariasis drug distribution system through door-to-door approach is an effort that is considered to be able to achieve the coverage of filariasis mass treatment and high medication behavior. ${ }^{19}$ This is due to the public's perception of filariasis prevention drugs that do not need to be taken if they do not suffer from the disease. So that people only accept the medicine but don't drink it.

\section{CONCLUSION}

There is a relationship between attitude toward filariasis $(\mathrm{p}$-value $=0.030)$ and TPE support $(\mathrm{p}$-value $=0.007)$. Variable TPE support is the most influential factor on the behavior of taking drugs to prevent filariasis after being controlled by attitude variables towards filariasis.

Suggestions from this study include the following.

\section{A. For the Community}

Enhance the participation of the community in participating in the prevention program for filariasis transmission given by the health center or health office.

\section{B. For the Government}

Improve public health services. Efforts that can be done are to increase counseling to the community regarding prevention of filariasis transmission and mass treatment programs for prevention of filariasis in Banyuasin District, and the distribution of information evenly.

\section{For the Researcher}

Researchers are expected to conduct similar research, but by adding other variables such as social economics, perceptions of susceptibility to filariasis, perceptions of the severity of filariasis, perceptions of the benefits of filariasis prevention, and perceptions of barriers to prevention of filariasis.

\section{REFERENCES}

[1] Adhikari. Factors Determining Non-Compliance to Mass Drug Administration for Lymphatic Filariasis Elimination in Endemic Districts of Nepal. JNHRC. 2014; 12(2).

[2] Alamsyah, Agus, \& Marlina, T. Faktor-Faktor yang Berhubungan dengan Cakupan Menelan Obat Massal Pencegah Filariasis. 2016. Available https://doi.org/DOI:http://dx.doi.org/10.22216/jen.vlil.586

[3] Ambarita, Taviv, Sitorus, Pahlevi, \& Kasnodihardjo. Perilaku Masyarakat terkait Penyakit Kaki Gajah dan Program Pengobatan Massal di Kecamatan Pemayung Kabupaten Batanghari, Jambi. Media Litbangkes. 2014; 24(4): 191-198.

[4] Departemen Kesehatan Republik Indonesia Direktorat Jenderal PP \& PL. Eliminasi Penyakit Kaki Gajah (Filariasis) di Indonesia. Jakarta; 2002.

[5] Departemen Kesehatan RI. Pedoman Pengobatan Massal Filariasis. Jakarta; 2006.

[6] Dinas Kesehatan Kabupaten Banyuasin. Laporan Tahunan Eliminasi Penyakit Kaki Gajah Kabupaten Banyuasin Provinsi Sumatera Selatan. Banyuasin; 2011.

[7] Dinas Kesehatan Kabupaten Banyuasin. Laporan Tahunan Eliminasi Penyakit Kaki Gajah Kabupaten Banyuasin Provinsi Sumatera Selatan. Banyuasin; 2017. 
[8] Dinas Kesehatan Kota Palembang. Profil Kesehatan Kota Palembang Tahun 2014. Palembang; 2014.

[9] Hamidi, Syarif, N., \& Asmawati. Hubungan Pengetahuan dan Sikap Kepala Keluarga tentang Filariasis dengan Mengonsumsi Obat Pencegahan Filariasis di Desa Berancah Wilayah UPT Puskesmas Selatbaru Tahun 2016. Jurnal Ners Universitas Pahlawan Tuanku Tambusai. 2017; 1(2): 57-72.

[10] Kusumawardhani. Gambaran Faktor-faktor Predisposisi dan Praktik Minum Obat pada Pengobatan Massal Filariasis di RW 7 Kelurahan Bakti Jaya Depok. 2009.

[11] Noerjoedianto, Ekawaty, \& Herwansyah. Pengaruh Karakteristik Kepala Keluarga terhadap Pencegahan Penyakit Filariasis di Desa KEmingking dalam Kabupaten Muaro Jambi Propinsi Jambi Tahun 2012. Universitas Jambi. 2012.

[12] Notoatmodjo. Pengantar Pendidikan Kesehatan Ilmu Perilaku. Yogyakarta: Andi Offset; 2003.

[13] Nujum, Z. Factors Determining Non-Compliance to Mass Drug Administration for Lymphatic Filariasis Elimination. 2012; 2(3): 109-115. Retrieved from www.tropicalparasitology.org.

[14] Nurlaila, Ginanjar, P., \& Martini. Faktor-Faktor yang Berhubungan dengan Kepatuhan Pengobatan Massal di Kelurahan Non Endemis Filariasis Kota Pekalongan. Jurnal Undip Online. 2017; 5(4). Retrieved from http://ejournal3.undip.ac.id/index.php/jkm.

[15] Purwantyastuti. Filariasis Di Indonesia: Pemberian Obat Massal Pencegahan (POMP) Filariasis. Buletin Jendela Epidemiologi. 2010; 1: 15-19.

[16] Santhi. Kepatuhan Minum Obat Filariasis pada Pengobatan Massal Berdasarkan Teori Health Belief Model di Kelurahan Limo Depok Tahun 2011. Jakarta: Universitas Indonesia; 2012.

[17] Santoso, Oktariana, Ambarita, R., \& Sudomo, L.. Epidemiologi Filariasis di Desa Sungai Rengit Kecamatan Talang Kelapa Kabupaten Banyuasin Tahun 2006. Buletin Penelitian Kesehatan. 2008; 36(2): 56-70.

[18] Sriyono. Pengaruh Tingkat Pendidikan dan Pemahaman Masyarakat Tentang Ikan Berformalin Terhadap Kesehatan Masyarakat. Faktor Exacta. 2015; 8(1): 79-91.

[19] Tomar, \& Kusnanto. Proses Pengobatan Massal Filariasis di Kepulauan Mentawai (19 ed.). Yogyakarta; 2007.

[20] World Health Organization. Preparing and Impelementing A National Plan to Eliminate Lymphatic Filariasis. Geneva; 2000.

[21] World Health Organization. Global Programme to Eliminate Lymphatic Filariasis Progress Report 2015. Switzerland; 2015.

\section{AUTHORS AFFILIATION.}

Indri Wulandari Putri from Faculty of Public Health Universitas Sriwijaya, Jln. Raya Palembang-Prabumulih KM.32 Indralaya, Ogan Ilir, 30862. My area of interest is social science.

Rini Mutahar, Faculty of Public Health Universitas Sriwijaya, Jln. Raya Palembang-Prabumulih KM.32 Indralaya, Ogan Ilir, 30862. My area of interest is health and social sciences.

Januar Sitorus from Faculty of Public Health Universitas Sriwijaya, Jln. Raya Palembang-Prabumulih KM.32 Indralaya, Ogan Ilir, 30862. My area of interest is social science.

Novrikasari from faculty of Public Health Universitas Sriwijaya, Jln. Raya Palembang-Prabumulih KM.32 Indralaya, Ogan Ilir, 30862. My area of interest is research and development.

Amrina Rosyada from faculty of Public Health Universitas Sriwijaya, Jln. Raya Palembang-Prabumulih KM.32 Indralaya, Ogan Ilir, 30862. My area of interest is social science.

Desheila Andarini from faculty of Public Health Universitas Sriwijaya, Jln. Raya Palembang-Prabumulih KM.32 Indralaya, Ogan Ilir, 30862. My area of research is health and social science. 